\title{
EKSPERIMENTASI MODEL PEMBELAJARAN KOOPERATIF TIPE TEAMS GAMES TOURNAMENTS DAN TEAM ASSISTED INDIVIDUALIZATION PADA MATERI GARIS DAN SUDUT DITINJAU DARI KECERDASAN EMOSIONAL SISWA KELAS VII SMP NEGERI SE-KABUPATEN MAGETAN TAHUN PELAJARAN 2013/2014
}

\author{
Pradipta Annurwanda $^{1}$, Mardiyana ${ }^{2}$ dan Dewi Retno Sari Saputro ${ }^{3}$ \\ 1,2,3 Prodi Magister Pendidikan Matematika, PPs Universitas Sebelas Maret Surakarta
}

\begin{abstract}
This aim of the research was to know the effect of learning models on mathematics achievement viewed from the student emotional intelligences. The learning model compared were TGT, TAI and direct learning. The type of the research was a quasi-experimental. The population was all of student seventh grade of junior high school in Magetan regency on academic year 2013/2014. The sampling technique by using a stratified cluster random sampling. The size of the sample was 252 students with 85 students as experimental class I, 86 students as experimental class II, 81 students as control class. The data collections were taken by document, questionnaire and test method. Hypothesis testing was performed by using an unbalanced two way analysis of variance. The conclusions of the research were as follows: (1) TGT learning model give better mathematics achievement than TAI and direct learning model, TAI learning model give an equal mathematics achievement to direct learning model, (2) the high level emotional intelligence students have an equal mathematics achievement to the middle level emotional intelligence students, the high level emotional intelligence students have better mathematics achievement than the low level emotional intelligence students, the middle level emotional intelligence students have better mathematics achievement than the low level emotional intelligence students, (3) for the high level emotional intelligence students, TGT, TAI and direct learning models give the same mathematics achievement, for the middle level emotional intelligence students, TGT learning model give the same mathematics achievement as TAI and direct learning model, direct learning model give better mathematics achivement than TAI learning model, for the low level emotional intelligence students, TGT learning model give the same mathematics achievement as TAI learning model, TGT learning model give better mathematics achievement than direct learning model, TAI learning model give the same mathematics achievement as direct learning model, (4) on the TGT and TAI learning models, students in each level of emotional intelligence have the same mathematics achievement, for student with direct learning model, the high level emotional intelligence students have the same mathematics achievement as middle and low level emotional intelligence students, the middle level emotional intelligence students have better mathematics achievement than low level emotional intelligence students.

Keywords: Teams Games Tournaments, Team Assisted Individualization, direct learning, emotional intelligence.
\end{abstract}

\section{PENDAHULUAN}

Matematika merupakan salah satu ilmu yang mendasari perkembangan teknologi modern dan mempunyai peran penting dalam berbagai disiplin ilmu untuk menata pola pikir siswa. Oleh karena itu matematika diajarkan sejak sekolah dasar hingga sekolah 
tinggi. Namun oleh sebagian besar siswa, pelajaran matematika dianggap sebagai mata pelajaran yang cukup sulit dipahami sehingga siswa mendapatkan nilai yang tidak optimal. Menurut Badan Standar Nasional Pendidikan (2013) mengenai laporan hasil ujian nasional SMP Negeri kabupaten Magetan tahun pelajaran 2012/2013 menunjukkan rata-rata Bahasa Indonesia sebesar 7,51, Bahasa Inggris sebesar 5,32, Matematika sebesar 4,62 dan IPA sebesar 5,37. Hal ini menunjukkan bahwa rata-rata hasil ujian nasional matematika lebih rendah dibandingkan dengan hasil ujian nasional Bahasa Indonesia, Bahasa Inggris dan IPA. Apabila ditelaah lebih jauh, daya serap siswa-siswi SMP di Kabupaten Magetan pada materi garis dan sudut mendapatkan hasil yang kurang optimal. Daya serap soal matematika ujian nasional SMP Kabupaten Magetan tahun pelajaran 2012/2013 pada materi menyelesaikan masalah yang berkaitan dengan hubungan dua garis menunjukkan bahwa persentase untuk tingkat kabupaten sebesar $31,18 \%$, tingkat provinsi sebesar $52,50 \%$ dan tingkat nasional sebesar 43,12\%. Hal ini menunjukkan bahwa siswa masih mengalami kesulitan dalam menguasai materi matematika khususnya pada pokok bahasan garis dan sudut.

Faktor yang muncul sehingga menyebabkan rendahnya prestasi belajar matematika cukup banyak. Baik faktor internal yang muncul dari dalam diri siswa maupun faktor eksternal yang muncul dari luar diri siswa. Kecerdasan emosional siswa merupakan faktor eksternal yang juga berpengaruh dalam prestasi belajar matematika siswa. Singh (2004) menyatakan bahwa, "EI as a type of social intelligence that involves ability to monitor one's own and other emotions, to discriminate among them, and to use the information to guide one's thingking and actions", yang artinya EI adalah jenis kecerdasan sosial yang melibatkan kemampuan untuk memantau emosi diri sendiri dan orang lain, untuk membedakan antara mereka dan menggunakan informasi tersebut untuk memandu seseorang berpikir dan bertindak. Kecerdasan emosional merupakan kemampuan untuk menggunakan dan mengelola emosi diri sendiri dan orang lain dan kaitannya dalam mengembangkan potensi diri sendiri dan orang lain. Kaitannya dengan prestasi belajar matematika, Supatmono (2009) menyebutkan bahwa matematika merupakan kegiatan pembangkitan masalah dan pemecahan masalah. Prestasi belajar matematika adalah tingkat penguasaan pengetahuan seseorang setelah melaksanakan kegiatan dan proses pembelajaran matematika dan ditunjukkan dalam bentuk nilai dari suau tes pada kompetensi tertentu. 
Salah satu model pembelajaran yang menarik diterapkan dalam pembelajaran matematika adalah model pembelajaran Teams Games Tournaments (TGT). Model yang dikembangkan oleh David De Vries dan Keath Edward ini memberikan kesempatan kepada siswa untuk memainkan permainan dengan anggota-anggota tim lain untuk memperoleh tambahan poin untuk skor tim mereka. Hasil penelitian Lai, et al. (2012) menyatakan bahwa ketika siswa bermain game, mereka dapat lebih fokus pada kegiatan pembelajaran kooperatif dan ingin menang. Sepanjang siswa bermain game, mereka akan tertarik pada isi kursus dan meningkatkan motivasi diri dan prestasi belajar mereka. Hasil penelitian van Wyk (2011) menyatakan bahwa skor tes prestasi untuk kelompok TGT adalah 52,99, sedangkan kelompok kontrol adalah 50,13. Ini berarti tes prestasi yang dilakukan pada kelompok TGT lebih baik dibandingkan dengan kelompok kontrol.

Model pembelajaran lain yang sesuai dengan teori konstruktivisme adalah model pembelajaran Team Assisted Individualization (TAI). TAI merupakan model pembelajaran yang mampu mengkombinasikan keampuhan kooperatif dan pengajaran individual. Dalam model pembelajaran TAI, siswa ditempatkan dalam kelompokkelompok kecil yang heterogen untuk menyelesaikan tugas kelompok yang sudah disiapkan oleh guru, selanjutnya diikuti dengan pemberian bantuan secara individu bagi siswa yang memerlukannya. Nneji (2011) menyatakan bahwa, "the team assisted individualized strategy is the most efficient of the treatment conditions and the direction of decreasing effect of instructional strategy on mathematics achievement." yang artinya strategi team assisted individualization adalah adalah strategi yang paling efisien dari kondisi pengobatan dan arah pengaruh strategi pembelajaran terhadap prestasi matematika yang menurun. Hal itu diperkuat dengan hasil penelitian Awofala dan Nneji (2012) yang menyatakan bahwa "the mathematics achievement of students exposed to the TAI is significantly higher than those of the CGS group", yang artinya prestasi matematika siswa yang dikenai model pembelajaran TAI secara signifikan lebih tinggi daripada model pembelajaran konvensional.

Tujuan dalam penelitian adalah untuk mengetahui: (1) manakah prestasi belajar matematika yang lebih baik antara prestasi belajar siswa yang dikenai model pembelajaran TGT, model pembelajaran TAI atau model pembelajaran langsung, (2) manakah prestasi belajar matematika yang lebih baik antara siswa yang memiliki kecerdasan emosional tinggi, siswa yang memiliki kecerdasan emosional sedang atau 
siswa yang memiliki kecerdasan emosional rendah, (3) manakah prestasi belajar matematika siswa yang lebih baik antara siswa yang dikenai model pembelajaran TGT, model pembelajaran TAI atau model pembelajaran langsung pada masing-masing tingkat kecerdasan emosional, (4) manakah prestasi belajar matematika yang lebih baik antara siswa yang memiliki kecerdasan emosional tinggi, siswa yang memiliki kecerdasan emosional sedang atau siswa yang memiliki kecerdasan emosional rendah pada masingmasing model pembelajaran.

\section{METODE PENELITIAN}

Penelitian ini dilaksanakan di Sekolah Menengah Pertama Negeri di Kabupaten Magetan pada bulan Desember 2013 sampai dengan bulan Juni 2014. Subjek penelitian ini adalah siswa kelas VII semester genap tahun pelajaran 2013/2014. Jenis penelitian yang dilakukan adalah penelitian eksperimental semu. Populasinya adalah seluruh siswa kelas VII Sekolah Menengah Pertama di Kabupaten Magetan tahun pelajaran 2013/2014. Teknik pengambilan sampel yang digunakan pada penelitian ini adalah stratified cluster random sampling. Sampelnya berjumlah 252 siswa yaitu siswa kelas VII yang diambil dari tiga sekolah yaitu SMPN 1 Maospati untuk kategori tinggi, SMPN 2 Karangrejo untuk kategori sedang, dan SMPN 1 Panekan untuk kategori rendah. Masingmasing sekolah diambil tiga kelas, dua kelas sebagai kelas eksperimen yang dikenai model pembelajaran TGT dan TAI, satu kelas sebagai kelas kontrol yang dikenai model pembelajaran langsung. Variabel terikat pada penelitian ini adalah prestasi belajar matematika pada materi garis dan sudut dan variabel bebasnya adalah model pembelajaran dan tingkat kecerdasan emosional. Metode pengumpulan data yang digunakan pada penelitian ini adalah metode tes, metode dokumentasi, dan metode angket. Teknik analisis data yang digunakan adalah uji keseimbangan dengan analisis variansi satu jalan sel tak sama. Prasyarat ujinya adalah uji normalitas dengan metode Lilliefors dan uji homogenitas dengan metode Bartlett. Uji hipotesis dilakukan dengan analisis variansi dua jalan sel tak sama dan dilanjutkan dengan uji komparasi ganda dengan metode Scheffe'.

\section{HASIL PENELITIAN DAN PEMBAHASAN}


Hasil uji coba instrumen tes prestasi yang dilaksanakan kepada 32 responden menunjukkan bahwa dari 36 soal yang diujicobakan terdapat 8 butir soal yang tidak memenuhi karena termasuk dalam soal kategori mudah atau sukar. Kemudian setelah dilakukan perhitungan daya pembeda diperoleh 4 butir soal yang memiliki daya pembeda yang tidak baik. Dalam penelitian ini instrumen tes prestasi belajar yang digunakan adalah 25 soal dan memiliki indeks reliabilitas sebesar 0,8529. Angket yang diujicobakan sebanyak 56 butir dan hasil perhitungan indeks konsistensi internal menunjukkan bahwa terdapat 11 butir angket tidak memenuhi kriteria karena indeks konsistensi internalnya kurang dari 0,30. Oleh karena itu angket yang digunakan dalam penelitian ini adalah 40 butir dengan indeks reliabilitas sebesar 0,8727. Hasil uji keseimbangan menggunakan uji analisis variansi satu jalan sel tak sama diperoleh $F_{o b s}=2,6986$ dan $F_{a ; 2 ; 249}=2,9975$ dengan $D K=\{F \mid F>2,9975\}$ sehingga $F_{\text {obs }} \notin D K$. Hal ini berarti ketiga populasi memiliki kemampuan awal sama.

Uji normalitas digunakan untuk mengetahui apakah suatu sampel berasal dari populasi yang berdistribusi normal atau tidak. Uji normalitas yang digunakan adalah dengan metode Lilliefors karena data yang diperoleh merupakan data tunggal. Rangkuman uji normalitas untuk masing-masing sampel ditunjukkan pada Tabel 1.

Tabel 1. Uji Normalitas Data Prestasi Belajar

\begin{tabular}{lcccc}
\hline \multicolumn{1}{c}{ Kategori } & $\mathrm{L}_{\text {obs }}$ & $\mathrm{L}_{(0,05 ; \mathrm{n})}$ & Keputusan Uji & Kesimpulan \\
\hline TGT & 0,0688 & 0,0961 & $\mathrm{H}_{0}$ tidak ditolak & Berdistribusi Normal \\
TAI & 0,0932 & 0,0955 & $\mathrm{H}_{0}$ tidak ditolak & Berdistribusi Normal \\
Langsung & 0,0798 & 0,0984 & $\mathrm{H}_{0}$ tidak ditolak & Berdistribusi Normal \\
Tinggi & 0,0918 & 0,1023 & $\mathrm{H}_{0}$ tidak ditolak & Berdistribusi Normal \\
Sedang & 0,0819 & 0,0849 & $\mathrm{H}_{0}$ tidak ditolak & Berdistribusi Normal \\
Rendah & 0,0985 & 0,1074 & $\mathrm{H}_{0}$ tidak ditolak & Berdistribusi Normal \\
\hline
\end{tabular}

Berdasarkan uji normalitas yang terangkum pada Tabel 1 terlihat bahwa $\mathrm{L}_{\mathrm{obs}}$ untuk setiap kategori lebih kecil dari $\mathrm{L}_{(0,05 ; \mathrm{n})}$, dengan $\mathrm{DK}=\left\{\mathrm{L} \mid \mathrm{L}>\mathrm{L}_{(0,05 ; \mathrm{n})}\right\}$ maka $\mathrm{L}_{\mathrm{obs}} \notin \mathrm{DK}$. Dengan demikian dapat disimpulkan bahwa data pada masing-masing kategori model pembelajaran dan masing-masing kategori tingkat kecerdasan emosional siswa berasal dari populasi yang berdistribusi normal.

Uji homogenitas variansi populasi dilakukan untuk mengetahui apakah sampel berasal dari populasi yang mempunyai variansi sama. Dalam penelitian ini dilakukan dua kali uji homogenitas variansi populasi, yaitu uji homogenitas data prestasi ditinjau dari model pembelajaran dan uji homogenitas data prestasi ditinjau dari kecerdasan 
emosional. Rangkuman hasil uji homogenitas disajikan pada Tabel 2.

Tabel 2. Uji Homogenitas Data Prestasi Belajar

\begin{tabular}{lcccl}
\hline \multicolumn{1}{c}{ Kategori } & $\chi_{\text {obs }}^{2}$ & $\chi^{2}{ }_{(0,05 ; 2)}$ & Keputusan Uji & \multicolumn{1}{c}{ Kesimpulan } \\
\hline $\begin{array}{l}\text { Model } \\
\begin{array}{l}\text { Pembelajaran } \\
\text { Kecerdasan } \\
\text { Emosional }\end{array}\end{array}$ & 3,2230 & 5,9910 & $\mathrm{H}_{0}$ tidak ditolak & $\begin{array}{l}\text { Variansi populasi } \\
\text { homogen }\end{array}$ \\
\hline
\end{tabular}

Berdasarkan uji homogenitas yang terangkum pada Tabel 2 terlihat jika DK = $\left\{\chi^{2} / \chi^{2}>\chi_{\alpha ;(k-1)}^{2}=5,991\right\}$ maka $\chi^{2}$ obs $\notin \mathrm{DK}$ sehingga keputusan ujinya adalah $\mathrm{H}_{0}$ tidak ditolak. Berdasarkan keputusan uji tersebut maka dapat disimpulkan bahwa variansi populasi homogen.

Uji hipotesis menggunakan analisis variansi dua jalan sel tak sama dengan tingkat signifikan 5\% dan diperoleh hasil seperti berikut.

Tabel 3. Rangkuman Analisis Variansi Dua Jalan Sel tak Sama

\begin{tabular}{lccccc}
\hline \multicolumn{1}{c}{ Sumber } & $\mathrm{JK}$ & $\mathrm{dk}$ & $\mathrm{RK}$ & $F_{\text {obs }}$ & $F_{\alpha}$ \\
\hline Model Pembelajaran (A) & 1248,3923 & 2 & 624,1962 & 8,1480 & 3,00 \\
Kecerdasan Emosional (B) & 1150,3513 & 2 & 575,1756 & 7,5081 & 3,00 \\
Interaksi (AB) & 2761,0202 & 4 & 690,2551 & 9,0103 & 2,37 \\
Galat & 18615,5685 & 243 & 76,6073 & - & - \\
Total & 23775,3323 & 251 & - & - & - \\
\hline
\end{tabular}

Berdasarkan uji analisis variansi dua jalan yang terangkum pada Tabel 3 terlihat bahwa semua nilai $\mathrm{F}_{\mathrm{obs}}>\mathrm{F}_{\alpha}$, sehingga diperoleh keputusan uji $\mathrm{H}_{0 \mathrm{~A}}$ ditolak, $\mathrm{H}_{0 \mathrm{~B}}$ ditolak dan $\mathrm{H}_{0 \mathrm{AB}}$ ditolak. Dengan demikian dapat disimpulkan: (1) prestasi belajar antara siswa yang dikenai model pembelajaran TGT, model pembelajaran TAI dan model pembelajaran langsung berbeda, (2) prestasi belajar siswa yang memiliki kecerdasan emosional tinggi, siswa yang memiliki kecerdasan emosional sedang dan siswa yang memiliki kecerdasan emosional rendah berbeda, (3) terdapat interaksi antara model pembelajaran dan kecerdasan emosional siswa terhadap prestasi belajar.

Berdasarkan kesimpulan analisis variansi dua jalan sel tak sama di atas, perlu dilakukan uji lanjut pasca anava dengan metode Scheffe' dan dicari terlebih dahulu rerata masing-masing sel dan rerata marginalnya. Rerata masing-masing sel dan rerata marginal tersaji pada Tabel 4 berikut.

Tabel 4. Rerata masing-masing Sel dan Rerata Marginal 
JMEE Volume IV Nomor 2, Desember 2014

\begin{tabular}{lcccc}
\hline \multirow{2}{*}{ Model Pembelajaran } & \multicolumn{3}{c}{ Kecerdasan Emosional } & \multirow{2}{*}{ Rerata Marginal } \\
\cline { 2 - 4 } & Tinggi & Sedang & Rendah & \\
\hline TGT & 74,2609 & 68,9000 & 72,3636 & 71,2471 \\
TAI & 72,3077 & 65,2571 & 65,2800 & 67,3953 \\
Langsung & 66.4615 & 73,6471 & 59,6190 & 67,7037 \\
Rerata Marginal & 70,8800 & 69,2110 & 65,8235 & \\
\hline
\end{tabular}

Hasil perhitungan analisis variansi diperoleh $\mathrm{H}_{0 \mathrm{~A}}$ ditolak. Karena terdapat 3 model pembelajaran, maka untuk mengetahui manakah yang secara signifikan mempunyai rerata berbeda perlu dilakukan uji lanjut pasca anava. Berikut rangkuman perhitungan uji lanjut rerata antar baris tersaji pada Tabel 5 .

Tabel 5. Komparasi Rerata antar Baris

\begin{tabular}{cccl}
\hline $\mathrm{H}_{0}$ & $\mathrm{~F}_{\text {obs }}$ & 2. $F_{0,05 ; 2,243}$ & \multicolumn{1}{c}{ Keputusan Uji } \\
\hline$\mu_{1 .}=\mu_{2 .}$ & 8,2786 & 6,00 & $\mathrm{H}_{0}$ ditolak \\
$\mu_{1 .}=\mu_{3 .}$ & 6,7976 & 6,00 & $\mathrm{H}_{0}$ ditolak \\
$\mu_{2 .}=\mu_{3 .}$ & 0,0518 & 6,00 & $\mathrm{H}_{0}$ tidak ditolak \\
\hline
\end{tabular}

Berdasarkan Tabel 5 dan Tabel 4, dapat disimpulkan bahwa prestasi belajar matematika pada siswa yang dikenai model pembelajaran TGT lebih baik daripada siswa yang dikenai model pembelajaran TAI maupun model pembelajaran langsung, prestasi belajar matematika siswa yang dikenai model pembelajaran TAI sama dengan siswa yang dikenai model pembelajaran langsung. Hal ini sesuai dengan Okataviani (2012) yang menyatakan bahwa model pembelajaran TGT memberikan prestasi belajar matematika yang lebih baik dari model pembelajaran konvensional dan diperkuat hasil penelitian Hidayati (2014) yang menyatakan bahwa prestasi belajar siswa yang dikenai TGT lebih baik daripada jigsaw dan konvensional.

Hasil perhitungan analisis variansi diperoleh $\mathrm{H}_{0 \mathrm{~B}}$ ditolak. Karena terdapat 3 kategori kecerdasan emosional, maka untuk mengetahui manakah yang secara signifikan mempunyai rerata berbeda perlu dilakukan uji lanjut pasca anava. Berikut rangkuman perhitungan uji lanjut rerata antar baris tersaji pada Tabel 6 .

Tabel 6 Komparasi Rerata antar Kolom

\begin{tabular}{crcl}
\hline $\mathrm{H}_{0}$ & \multicolumn{1}{c}{$\mathrm{F}_{\mathrm{obs}}$} & \multicolumn{1}{c}{ Keputusan Uji } \\
\hline$\mu_{.1}=\mu_{.2}$ & 1,6155 & 6,00 & $\mathrm{H}_{0}$ tidak ditolak \\
$\mu_{.1}=\mu_{.3}$ & 11,9031 & 6,00 & $\mathrm{H}_{0}$ ditolak \\
$\mu_{.2}=\mu_{.3}$ & 6,2726 & 6,00 & $\mathrm{H}_{0}$ ditolak \\
\hline
\end{tabular}

Berdasarkan Tabel 6 dan Tabel 4, dapat disimpulkan bahwa siswa yang memiliki tingkat kecerdasan emosional tinggi mempunyai prestasi belajar matematika yang sama dengan 
siswa yang memiliki tingkat kecerdasan emosional sedang, siswa yang memiliki tingkat kecerdasan emosional tinggi mempunyai prestasi belajar matematika yang lebih baik daripada siswa yang memiliki tingkat kecerdasan emosional rendah, siswa yang memiliki tingkat kecerdasan emosional sedang mempunyai prestasi belajar matematika yang lebih baik daripada siswa yang memiliki tingkat kecerdasan emosional rendah. Hal ini sesuai dengan hasil penelitian Nwadinigwe \& Obieke (2012) yang menyatakan bahwa terdapat hubungan positif antara keterampilan kecerdasan emosional dengan prestasi akademik sehingga pengembangan keterampilan kecerdasan emosional siswa akan mengarah pada peningkatan/prestasi akademiknya.

Hasil perhitungan analisis variansi diperoleh $\mathrm{H}_{0 \mathrm{AB}}$ ditolak. Dilihat dari masingmasing tingkat kecerdasan emosional, maka untuk mengetahui manakah yang secara signifikan mempunyai rerata berbeda perlu dilakukan uji lanjut pasca anava. Berikut rangkuman uji lanjut rerata antar sel pada kolom yang sama tersaji pada Tabel 7.

Tabel 7 Komparasi Rerata antar Sel pada Kolom yang Sama

\begin{tabular}{crcl}
\hline $\mathrm{H}_{0}$ & \multicolumn{1}{c}{$\mathrm{F}_{\text {obs }}$} & $8 . F_{0,05 ; 8,243}$ & \multicolumn{1}{c}{ Keputusan Uji } \\
\hline$\mu_{11}=\mu_{21}$ & 0,6077 & 15,52 & $\mathrm{H}_{0}$ tidak ditolak \\
$\mu_{11}=\mu_{31}$ & 9,6906 & 15,52 & $\mathrm{H}_{0}$ tidak ditolak \\
$\mu_{21}=\mu_{31}$ & 5,7998 & 15,52 & $\mathrm{H}_{0}$ tidak ditolak \\
$\mu_{12}=\mu_{22}$ & 3,2336 & 15,52 & $\mathrm{H}_{0}$ tidak ditolak \\
$\mu_{12}=\mu_{32}$ & 5,4061 & 15,52 & $\mathrm{H}_{0}$ tidak ditolak \\
$\mu_{22}=\mu_{32}$ & 15,8469 & 15,52 & $\mathrm{H}_{0}$ ditolak \\
$\mu_{13}=\mu_{23}$ & 7,6649 & 15,52 & $\mathrm{H}_{0}$ tidak ditolak \\
$\mu_{13}=\mu_{33}$ & 22,7801 & 15,52 & $\mathrm{H}_{0}$ ditolak \\
$\mu_{23}=\mu_{33}$ & 4,7743 & 15,52 & $\mathrm{H}_{0}$ tidak ditolak \\
\hline
\end{tabular}

Berdasarkan Tabel 7 dan Tabel 4, dapat disimpulkan bahwa pada kategori tingkat kecerdasan emosional tinggi, siswa yang dikenai model pembelajaran TGT, TAI dan langsung mempunyai prestasi belajar matematika yang sama, pada kategori tingkat kecerdasan emosional sedang, prestasi belajar siswa yang dikenai model pembelajaran TGT sama dengan prestasi belajar siswa yang dikenai model pembelajaran TAI dan langsung, prestasi belajar siswa yang dikenai model pembelajaran langsung lebih baik daripada prestasi belajar siswa yang dikenai model pembelajaran TAI, pada kategori tingkat kecerdasan emosional rendah, prestasi belajar siswa yang dikenai model pembelajaran TGT sama dengan prestasi belajar siswa yang dikenai model pembelajaran TAI, prestasi belajar siswa yang dikenai model pembelajaran TGT lebih baik daripada 
prestasi belajar siswa yang dikenai model pembelajaran langsung, prestasi belajar siswa yang dikenai model pembelajaran TAI sama dengan prestasi belajar siswa yang dikenai model pembelajaran langsung. Hal ini sesuai dengan hasil penelitian Margono (2014) yang menyatakan bahwa siswa yang memiliki kecerdasan emosional tinggi mempunyai prestasi belajar yang sama pada model pembelajaran TGT, NHT dan langsung, siswa yang memiliki kecerdasan emosional rendah memiliki prestasi belajar yang sama pada model pembelajaran TGT, NHT dan langsung.

Hasil perhitungan analisis variansi diperoleh $\mathrm{H}_{0 \mathrm{AB}}$ ditolak. Dilihat dari masingmasing model pembelajaran, maka untuk mengetahui manakah yang secara signifikan mempunyai rerata berbeda perlu dilakukan uji lanjut pasca anava. Berikut rangkuman perhitungan uji lanjut rerata antar sel pada baris yang sama tersaji pada Tabel 8.

Tabel 8 Komparasi Rerata antar Sel pada Baris yang Sama

\begin{tabular}{crcl}
\hline $\mathrm{H}_{0}$ & $\mathrm{~F}_{\text {obs }}$ & $8 . F_{0,058,243}$ & \multicolumn{1}{c}{ Keputusan Uji } \\
\hline$\mu_{11}=\mu_{12}$ & 5,4783 & 15,52 & $\mathrm{H}_{0}$ tidak ditolak \\
$\mu_{11}=\mu_{13}$ & 0,5283 & 15,52 & $\mathrm{H}_{0}$ tidak ditolak \\
$\mu_{12}=\mu_{13}$ & 2,2227 & 15,52 & $\mathrm{H}_{0}$ tidak ditolak \\
$\mu_{21}=\mu_{22}$ & 9,6803 & 15,52 & $\mathrm{H}_{0}$ tidak ditolak \\
$\mu_{21}=\mu_{23}$ & 8,2167 & 15,52 & $\mathrm{H}_{0}$ tidak ditolak \\
$\mu_{22}=\mu_{23}$ & 0,0001 & 15,52 & $\mathrm{H}_{0}$ tidak ditolak \\
$\mu_{31}=\mu_{32}$ & 9,9300 & 15,52 & $\mathrm{H}_{0}$ tidak ditolak \\
$\mu_{31}=\mu_{33}$ & 7,0999 & 15,52 & $\mathrm{H}_{0}$ tidak ditolak \\
$\mu_{32}=\mu_{33}$ & 33,3471 & 15,52 & $\mathrm{H}_{0}$ ditolak \\
\hline
\end{tabular}

Berdasarkan Tabel 8 dan Tabel 4, dapat disimpulkan bahwa pada kategori model pembelajaran TGT, siswa yang memiliki tingkat kecerdasan emosional tinggi, siswa yang memiliki tingkat kecerdasan emosional sedang dan siswa yang memiliki tingkat kecerdasan emosional rendah mempunyai prestasi belajar matematika yang sama, pada kategori model pembelajaran TAI, siswa yang memiliki tingkat kecerdasan emosional tinggi, siswa yang memiliki tingkat kecerdasan emosional sedang dan siswa yang memiliki tingkat kecerdasan emosional rendah mempunyai prestasi belajar matematika yang sama, pada kategori model pembelajaran langsung, siswa yang memiliki tingkat kecerdasan emosional tinggi mempunyai prestasi belajar yang sama dengan siswa yang memiliki tingkat kecerdasan emosional sedang maupun rendah, dan siswa yang memiliki tingkat kecerdasan emosional sedang mempunyai prestasi belajar matematika yang lebih baik daripada siswa yang memiliki tingkat kecerdasan emosional rendah. 
JMEE Volume IV Nomor 2, Desember 2014

\section{SIMPULAN DAN SARAN}

Berdasarkan analisis data yang telah dilakukan, maka dapat disimpulkan: (1) prestasi belajar matematika pada siswa yang dikenai model pembelajaran TGT lebih baik daripada siswa yang dikenai model pembelajaran TAI maupun model pembelajaran langsung, prestasi belajar matematika siswa yang dikenai model pembelajaran TAI sama dengan siswa yang dikenai model pembelajaran langsung, (2) siswa yang memiliki tingkat kecerdasan emosional tinggi mempunyai prestasi belajar matematika yang sama dengan siswa yang memiliki tingkat kecerdasan emosional sedang, siswa yang memiliki tingkat kecerdasan emosional tinggi mempunyai prestasi belajar matematika yang lebih baik daripada siswa yang memiliki tingkat kecerdasan emosional rendah, dan siswa yang memiliki tingkat kecerdasan emosional sedang mempunyai prestasi belajar matematika yang lebih baik daripada siswa yang memiliki tingkat kecerdasan emosional rendah, (3a) pada kategori tingkat kecerdasan emosional tinggi, siswa yang dikenai model pembelajaran TGT, TAI dan langsung menghasilkan prestasi belajar matematika yang sama, (3b) pada kategori tingkat kecerdasan emosional sedang, prestasi belajar siswa yang dikenai model pembelajaran TGT sama dengan prestasi belajar siswa yang dikenai model pembelajaran TAI dan langsung, prestasi belajar siswa yang dikenai model pembelajaran langsung lebih baik daripada prestasi belajar siswa yang dikenai model pembelajaran TAI, (3c) pada kategori tingkat kecerdasan emosional rendah, prestasi belajar siswa yang dikenai model pembelajaran TGT sama dengan prestasi belajar siswa yang dikenai model pembelajaran TAI, prestasi belajar siswa yang dikenai model pembelajaran TGT lebih baik daripada prestasi belajar siswa yang dikenai model pembelajaran langsung, prestasi belajar siswa yang dikenai model pembelajaran TAI sama dengan prestasi belajar siswa yang dikenai model pembelajaran langsung, (4a) pada kategori model pembelajaran TGT, siswa yang memiliki tingkat kecerdasan emosional tinggi, siswa yang memiliki tingkat kecerdasan emosional sedang dan siswa yang memiliki tingkat kecerdasan emosional rendah mempunyai prestasi belajar matematika yang sama, (4b) pada kategori model pembelajaran TAI, siswa yang memiliki tingkat kecerdasan emosional tinggi, siswa yang memiliki tingkat kecerdasan emosional sedang dan siswa yang memiliki tingkat kecerdasan emosional rendah mempunyai prestasi belajar matematika yang sama, (4c) pada kategori model pembelajaran langsung, siswa yang memiliki tingkat kecerdasan emosional tinggi mempunyai prestasi belajar yang 
sama dengan siswa yang memiliki tingkat kecerdasan emosional sedang maupun rendah, dan siswa yang memiliki tingkat kecerdasan emosional sedang mempunyai prestasi belajar matematika yang lebih baik daripada siswa yang memiliki tingkat kecerdasan emosional rendah.

Berdasarkan simpulan dan dalam rangka turut mengembangkan pembelajaran matematika, maka dapat dikemukakan saran yaitu: (1) bagi guru matematika Sebaiknya guru menerapkan model pembelajaran langsung pada materi garis dan sudut karena pada hasil penelitian ini terbukti bahwa prestasi belajar matematika siswa yang memiliki kecerdasan emosional sedang yang dikenai model pembelajaran langsung lebih baik daripada model pembelajaran TGT dan TAI, (2) Untuk mengatasi kebosanan siswa pada saat guru menyampaikan materi dengan menggunakan model pembelajaran langsung, sebaiknya guru menyisipkan permainan pada model tersebut karena pada siswa yang memiliki kecerdasan emosional tinggi dan rendah memiliki prestasi yang lebih baik daripada siswa yang dikenai model pembelajaran TAI dan langsung, (3) bagi peneliti lain, hendaknya meneliti faktor-faktor lain yang diduga mempunyai hubungan positif dengan prestasi belajar siswa pada materi yang sama semisal ditinjau dari kemampuan interpersonal siswa.

\section{DAFTAR PUSTAKA}

Awofala, A. O. A., and Nneji, L. M. 2012. Effect of Framing and Team Assisted Individualized Instructional Strategies on Students' Achievement in mathematics. Unpublished Ph.D Thesis. University of Ibadan.

Badan Standar Nasional Pendidikan (BSNP). 2013. Laporan Hasil Ujian Nasional Tahun 2012/2013. Jakarta: Pusat Penelitian Pendidikan dan Pengembangan Kementrian Pendidikan Nasional.

Hidayati, N. 2014. Eksperimentasi Pembelajaran Matematika dengan Model Pembelajaran Kooperatif Jigsaw dan Teams Games Tournament Ditinjau dari Kecerdasan Intrapersonal Siswa. Jurnal Elektronik Pembelajaran Matematika. Vol.2, No.2, hal 152-162.

Lai, C. H., She, Y. X., Sung, C. Y., and Jong, B. S. 2012. The Game-Based Learning of Combining Competition and Cooperative Learning. Computers \& Education, vol 57(1), pp 1127-1136.

Margono, A., Budiyono, dan Sujadi, I. 2014. Eksperimentasi Model Pembelajaran Kooperatif Tipe Teams Games Tournament dan Numbered Heads Together Ditinjau dari Kecerdasan Emosional Siswa. Jurnal Elektronik Pembelajaran Matematika. Vol.2, No.2, hal 184-192. 
Nneji, L. 2011. Impact Of Framing And Team Assisted Individualized Instructional Strategies Students' Achievement In Basic Science In The North Central Zone Of Nigeria. Knowledge Review. Vol 23 No. 4.

Nwadinigwe, L. P., and Obieke, A. U. 2012. The Impact of Emotional Intelligence on Academic Achievement of Senior Secondary School Students in Lagos, Nigeria. Journal of Emerging Trends in Educational Research and Policy Studies (JETERAPS), 3(4): 395-401.

Oktaviani, R., Sapti, M., dan Nugraheni, P. 2012. Eksperimentasi Model Pembelajaaran Kooperatif Tipe TGT Terhadap Prestasi Belajar Matematika Ditinjau dari Motivasi Belajar Siswa Kelas VIII SMP Negeri 2 Buluspesantren Tahun Pelajaran 2011/2012. Pp 735-742. Kontribusi Pendidikan Matematika dan Matematika dalam Membangun Karakter Guru dan Siswa. FMIPA UNY.

Singh, S. 2004. Development of a Measure of Emotional Intelligence. National Academy of Psychology, India Vol. 49, Nos. 2-3, 136-141.

Supatmono, C. 2009. Matematika Asyik. Jakarta: PT Grasindo.

Van Wyk, M. M. 2011. The Effect of Teams-Games-Tournaments on Achievement, Retention, and Attitude of Economics Education Students. Journal of Social Science. 26(3): 183-193. 